\title{
DNAJB4 wt Allele
}

National Cancer Institute

\section{Source}

National Cancer Institute. DNAIB4 wt Allele. NCI Thesaurus. Code C62455.

Human DNAJB4 wild-type allele is located in the vicinity of 1 p31.1 and is approximately 12 $\mathrm{kb}$ in length. This allele, which encodes Dnaj homolog subfamily B member 4 protein, plays a role in the regulation of protein chaperone activity. The expression of the allele correlates negatively with cancer cell invasion ability. Further, it has been demonstrated to have an inhibitory effect on non-small-cell lung cancer development and is currently being investigated as a prognostic biomarker for the disease. 